\title{
Elements Identification in Golden Strawberries (Physalis Peruviana L.) using Wavelength Dispersive X-Ray Fluorescence
}

\section{Uğur Akbaba ${ }^{a}$}

Physics Education Department, Education Faculty, Kafkas University, 36100 Kars, Turkey

\begin{tabular}{l|l}
\hline A R T I C L E I N F O & A B S T R A C T \\
\hline Research Article & $\begin{array}{l}\text { Physalis peruviana }(P P) \text { is a popular exotic fruit due to its functional food properties. This product } \\
\text { has a wide range of uses in the medical field, including treatments for cancer, malaria, hepatitis, } \\
\text { dermatitis, rheumatism, weight loss, and diabetes. In this study, the PP element concentrations were } \\
\text { investigated using a Wave Dispersive X-ray Fluorescence Spectrometer (WDXRF) Al, Ca, Fe, Mn, } \\
\text { P, S, Zn, Cl, K, Mg, Na, F, Si, and B were detected, and the Ca, Fe, } \mathrm{Zn}, \mathrm{P}, \mathrm{Na}, \mathrm{Mg} \text { elements were } \\
\text { found in significant amounts. Therefore, } P P \text { has some important health elements. For example, Mg } \\
\text { and Mn may be associated with diabetes control. WDXRF is a cheap, quick, and non-destructive } \\
\text { technique used in the elemental analysis of plant samples. }\end{array}$ \\
Accepted : $25 / 03 / 2019$ &
\end{tabular}

Keywords:

Physalis peruviana

WDXRF

Element content

Herbal medicine

Herbal analysis

\section{Introduction}

The use of herbal products in traditional medicine has increased dramatically nowadays. Fruits, vegetables, and spices are rich in antioxidants. Therefore, they are widely used to protect against or treat serious diseases (Hassan et al., 2017). Due to its significant amounts of antioxidants, minerals, vitamins (pro-vitamin A, vitamin $\mathrm{C}$, and several vitamin $\mathrm{B}$ complexes), fiber, and bioactive compounds, $P P$ is one of the most popular and promising fruits used in herbal medicinal applications. For example, $P P$ is effective in the treatment of diabetes as it adjusts the level of glucose in the blood. $P P$ is also used in pterygia, pertussis, and dental health treatments. In addition, $P P$ has expectorant, diuretic, and anthelmintic properties, and it reduces the risk of various diseases, such as cancer, malaria, asthma, hepatitis, dermatitis, and rheumatism.

PP plants produce yellow and purple-colored bellshaped flowers during the winter and can grow vertically to $0.9 \mathrm{~m}$. The fruit weighs approximately $4-5$ grams and is covered with a yellow crust of yellow leaves. $P P$ is indigenous to the Andean highlands and belongs to the Solanaceae family (Ramadan, 2011; Etzbach et al., 2018; Wojcieszek et al., 2016; Hegadüs et al., 2018).
Many studies have identified the chemical and physical components of the $P P$ plant as well as its medical applications. For example, the ethanol extract of $P P$ inhibits growth and induces the apoptotic death of human Hep G2 cells in culture, but it does not harm healthy cells. Additional studies detail the molecular mechanism of $P P$ 's ethanol extract-induced apoptosis in Hep G2 cells. However, the effect of PP's ethanol extract depends on the application dose and time (Wu et al., 2004).

$P P$ is rich in withanolides as different withanolide species were isolated from this fruit. Withanolides have antimicrobial, antitumor, anti-inflammatory, hepatoprotective, immunomodulatory, and antibacterial properties (Fang et al., 2012; Lan et al., 2009; Sang-ngarn et al., 2016). The potential protective role of $P P$ on cadmium-induced hepatotoxicity and nephrotoxicity was also investigated. Similarly, the antihepatotoxic effects of $P P$ on carbon tetrachloride-induced acute liver injury in rats have been studied. In addition, the extract of $P P$ significantly reduced the histopathological changes induced by CCl4 (Dkhil et al., 2014; Arun et al., 2007). 
One study used a mass spectrometer with inductively coupled plasma (ICP MS) to characterize and determine the bioaccessibility of the cobalt, copper, and selenium in $P P$ and found that these elements were highly bioaccessible. However, $P P$ has not undergone large-scale element content detection. The identification of plants' elemental contents is important in determining their medical applications, as well as product quality, amount of used seed effect, the effect of harvest periods and shape of the product, and the effect of different parameters, such as water, humidity, pressure, soil, and terrain, on the product (Hegadüs et al., 2018; Akbaba et al., 2012(a); Martínez et al., 2010; Babalar et al., 2015; Golubkina et al., 2018)

Several methods have been used to determine PP's contents, including inductively coupled plasma-optical emission spectrometry (ICP-OES), the Singleton and Rossi method, the ferric-reducing ability of plasma (FRAP), energy dispersive X-ray fluorescence spectrometry (EDXRF), diode array detection (DAD), atmospheric pressure chemical ionization-mass spectrometry (APCIMS), and high-performance liquid chromatography (HPLC). Chemical techniques have a long, expensive process, including solution preparation and extrusion extraction, and the damage product rate is high (Etzbach et al., 2018, Hegadüs et al., 2018).

The aim of this study is to present an easy, fast, inexpensive, and non-destructive method of element analysis for $P P$. Wavelength dispersive $\mathrm{X}$-ray fluorescence (WDXRF) spectrometry is inexpensive, fast, simple, and not destructive to herbal samples. In addition, this technique is able to analyze both solid and liquid samples. The biggest disadvantage of WDXRF is that the system is sensitive to moisture (Akbaba et al., 2012a). Therefore, WDXRF was used in this exploration.

\section{Materials and Methods}

\section{Instruments}

An agate mortar, digital scale (Ohous TS 120), hydraulic press $\left(\right.$ SpexP $\left._{\max }=3.5 \times 10^{7} \mathrm{~kg} / \mathrm{m}^{2}\right)$, WDXRF spectrometer (ZSX-100e with a rhodium target X-ray controlled by ZSX software), and moisture extraction oven (temp. range of $40^{\circ} \mathrm{C}$ to $250^{\circ} \mathrm{C}, \mathrm{QED}$ ) were used in this study (Akbaba et al., 2012b). This system is capable of analyzing elements from Be (Beryllium) to U (Uranium). The WDXRF instrument consists of a detector, amplifier, discriminator, counter, and printer units and includes a 4 $\mathrm{kW} 70 \mathrm{kV}$ end-windows X-ray tube. The X-ray detector is used in proportional, gas flow, and scintillation spectrometry. The other features of this system include up to five primary beam filters, 10 analyzing crystals, eight limiting area diaphragms, optional secondary collimators, automatic sample changer, compact design, and multiwindow, multi-function fundamental parameters software. The discriminator filters the pulses coming from the detector and it allows those of a certain height to pass through; these pulses are saved in a recorder. If required, the system can show the number of pulses (of violence) as a function of the wavelength and the angle of the reflection spectrum in diagrams. A matrix-correction process is conducted automatically by the system, including line overlaps.
Rigaku has further improved their semi-quantitative software package with the introduction of SQX which can correct for secondary excitation effect by photoelectrons (light and ultra-light elements), varying atmospheres, impurities, and different sample sizes. Increased accuracy is then achieved using matching library and perfect scan analysis programs, and the fundamental parameter method is used to determine mass concentration by using measured counts. This approach compensates mathematically the overlapped matrix effects.

WDXRF is a unique technique to use when fast and accurate elemental analysis is needed; the equipment has obtained qualified results without needing advanced analytical skills (Stewart et al., 2015; Chein et al., 2015). Figure 1 shows the WDXRF system used here and its unit.

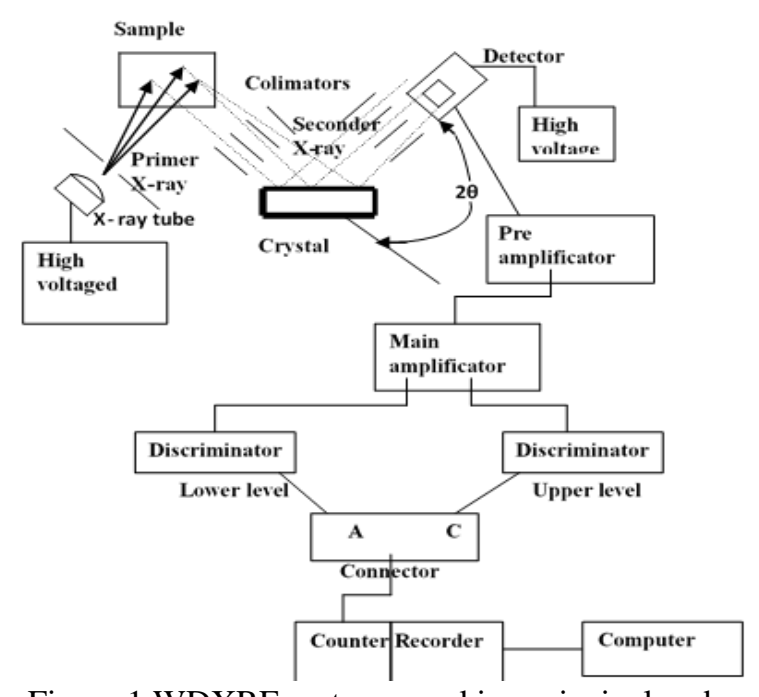

Figure 1 WDXRF systems working principal and connected units

\section{Sample Preparation}

PPs were purchased from a local certificated company in Aydın City, Turkey. The fruit had been harvested at the orange (OR) stage of maturity according to a skin color index (Galvis et al., 2005). The purchased PPs were dried and thoroughly pulverized in an agate mortar. As the measurement system can be adversely affected by moisture, the powdered samples were then dried at $45^{\circ} \mathrm{C}$ for 20 minutes in an oven, and because the baking process might affect the amount of dry matter and elemental content, the temperature and duration were kept low. The dried samples were pressed into uniform $20 \mathrm{~mm}$ pellets using a hydraulic press machine with a standing time of 60s; the samples were pelleted under five-ton pressure. Since the pellets were easily formed, no binder (e.g. cellulose microcrystalline) was required in the sample powders. Six pellets, each weighing $0.5 \mathrm{~g}$, were prepared to ensure statistical consistence. All samples were subsequently analyzed with a sequential ZSX 100e WDXRF spectrometer equipped with an Rh X-ray tube and automatic matrix correction. The average room temperature was $20-21^{\circ} \mathrm{C}$, and the environment was relatively dry. 


\section{Results and Discussion}

$\mathrm{Al}, \mathrm{Ca}, \mathrm{Fe}, \mathrm{Mn}, \mathrm{P}, \mathrm{S}, \mathrm{Zn}, \mathrm{Cl}, \mathrm{K}, \mathrm{Mg}, \mathrm{Na}, \mathrm{F}, \mathrm{Si}$, and B were detected in the golden berries. Figures 2 and 3 show the peaks and concentrations of these elements. It can be observed that PPs are particularly rich in $\mathrm{Zn}$ and $\mathrm{Mg}$, followed by Fe, Mn, F, S, Cl, K, Na, F, and Si.

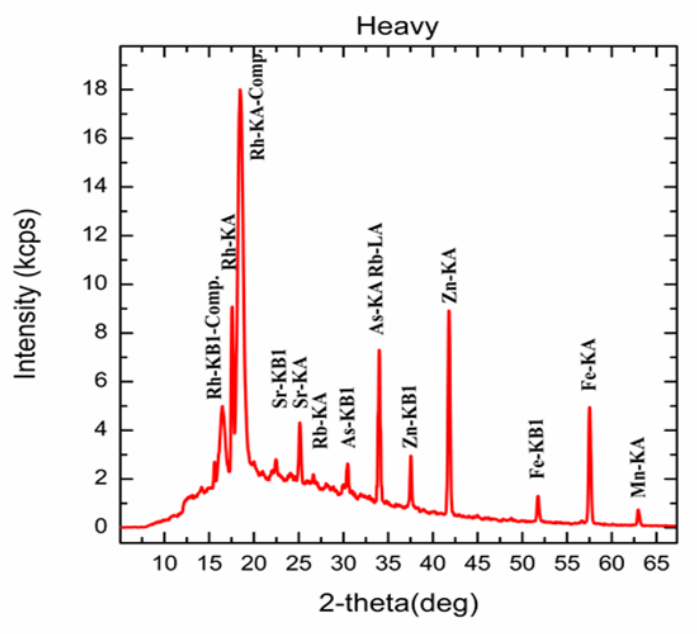

Figure 2 The intensities of heavy elements versus diffraction angle obtained from PP sample

These findings are consistent with other studies. Previous research to determine the elemental and antioxidant content of strawberries grown in Hungary identified $\mathrm{Al}, \mathrm{B}, \mathrm{Ba}, \mathrm{Ca}, \mathrm{Cu}, \mathrm{Fe}, \mathrm{K}, \mathrm{Mg}, \mathrm{Mn}, \mathrm{Na}, \mathrm{P}$, and $\mathrm{Zn}$, with $\mathrm{K}, \mathrm{P}, \mathrm{Ca}$, and $\mathrm{Mg}$ the most significantly detected elements in the samples (Hegadüs et al., 2018). In presented study heavy elements $\mathrm{As}, \mathrm{Pb}, \mathrm{Sr}$, and $\mathrm{Rh}$ have also been detected but due to the metal sample holder in the scans rather than the fruit itself. As outlined in Table 1 below, elements are determined for each sample in each measurement. $\mathrm{C}$ and $\mathrm{O}$ are not considered because they are found in every organic item, and the density of $\mathrm{Al}$ and $\mathrm{Cl}$ can be ignored due to very very low concentrations.

$\mathrm{Ca}$ contributes to bone and tooth development and is required for muscle contraction; it also adjusts the rate of cholesterol in the body, regulates heart and cell activity, and is necessary for blood coagulation and enzyme activation (Pravina, 2013). Fe is effective in cellular oxygen transport, and Fe deficiency causes anemia and fatigue (Abbaspour et al., 2014). Mn contributes to bone formation, blood sugar regulation, protein synthesis, and fat-carbohydrate metabolism; it is also a coenzyme and regulates hormone function.
$\mathrm{P}$, another element detected in the PPs, is effective in waste filtration, tissue and cell repair, DNA-RNA production, and muscle contraction. Also determined was $\mathrm{Mg}$, which aids bone health and relief from asthma, migraine, diabetes, and depression. $\mathrm{Na}$ was detected in high amounts, and this element is very important for heart health, metabolism, and acid-base balance (Martínez et al., 2010). Useful for the respiratory system and nourishing the brain, $\mathrm{S}$ is also necessary for healthy hair, nails, and skin, and it is antiallergic. Another key element is $\mathrm{Zn}$ which is particularly essential for enzymatic function but also supports the immune system and contributes to sexual development. In addition to being an antioxidant, $\mathrm{Zn}$ boosts the central nervous system (Akdeniz et al., 2016).

Furthermore, $\mathrm{K}$ was detected in the PPs, and this element is involved in balancing $\mathrm{PH}$ ratios and blood pressure. F, another important element for protecting dental health and preventing bone resorption, was also found in the sample. Low levels of $\mathrm{Si}$, which increases the benefits of glucose, calcium, and vitamin D, were determined. It has elsewhere been suggested that Si plays a role in the structural integrity of nails, hair, and skin, overall collagen synthesis, bone mineralization and health, reduced metal accumulation in Alzheimer's disease, immune system health, and the reduction of risk for atherosclerosis.

The last element listed in Table 1 is B, and, for the regulation of calcium, Vitamin $\mathrm{D}$, other minerals, and brain functions, B is essential. Moreover, B protects bond structure by reducing $\mathrm{Ca}$ and $\mathrm{Mg}$ losses (Demirtaş et. al., 2010). The presence of $\mathrm{Ca}, \mathrm{Mg}, \mathrm{F}$, and $\mathrm{B}$ is a positive indicator of tooth and bone health (Etzbach et al., 2018). Similarly, as can be seen from the literature review, elements such as $\mathrm{Ca}, \mathrm{P}, \mathrm{Zn}, \mathrm{Na}, \mathrm{Mg}$, and $\mathrm{K}$, which are highly detected in the PPs, have great importance for human health in numerous ways.

\section{Conclusion}

In this study, it was determined that a number of elements that are important for health exist in PP fruit. There is currently intensive advertising activity in the media that this fruit can be used to lose weight and, in particular, balance diabetes. On this point, the presence of $\mathrm{Mg}$ and Mn could be correlated with diabetes control by PPs because these elements were detected at considerable levels. Chemical analyses are generally long and costly approaches to the elemental analysis of plant samples; in contrast, the WDXRF technique used in this study is relatively cheap, non-destructive, and fast and can be used for elemental analysis of this kind.

Table 1 Some determined elements and concentrations in golden strawberry

\begin{tabular}{l|ccccc}
\hline Elements & Concentration $(\%)$ & Standard deviation & Elements & Concentration (\%) & Standard deviation \\
\hline $\mathrm{Al}$ & 0.0001 & $5.2 \times 10^{-5}$ & $\mathrm{Cl}$ & 0.0003 & $8.1 \times 10^{-5}$ \\
$\mathrm{Ca}$ & 2.5875 & 0.36264 & $\mathrm{~K}$ & 1.0043 & 0.25747 \\
$\mathrm{Fe}$ & 3.8234 & 0.47630 & $\mathrm{Mg}$ & 2.3694 & 0.22955 \\
$\mathrm{Mn}$ & 1.7661 & 0.14864 & $\mathrm{Na}$ & 3.2283 & 0.29809 \\
$\mathrm{P}$ & 2.0230 & 0.19062 & $\mathrm{~F}$ & 1.7377 & 0.18134 \\
$\mathrm{~S}$ & 0.0287 & 0.37778 & $\mathrm{Si}$ & 0.0531 & 0.00897 \\
$\mathrm{Zn}$ & 2.5416 & 0.27960 & $\mathrm{~B}$ & 1.0342 & 0.24863 \\
\hline
\end{tabular}



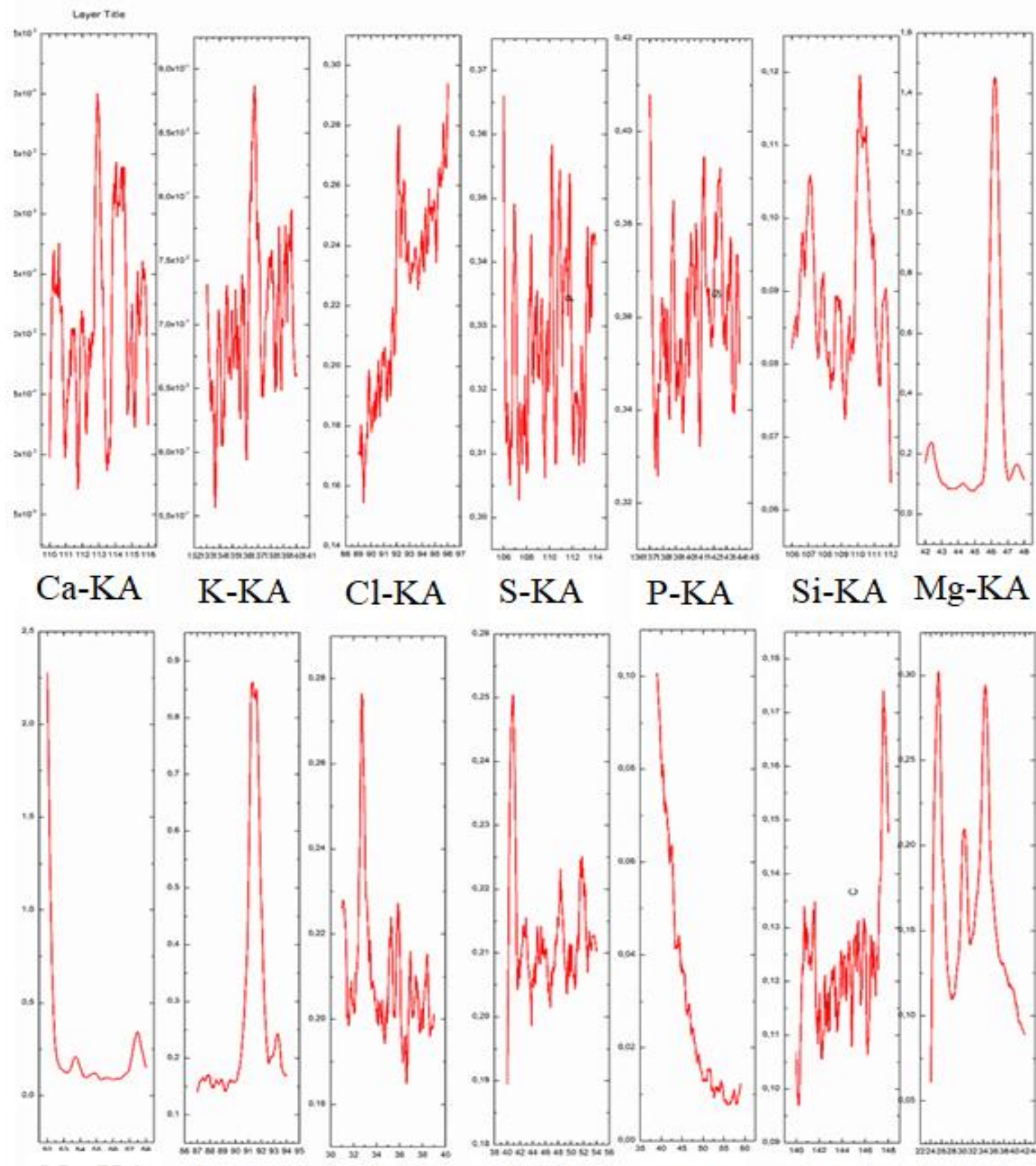

Na-KA
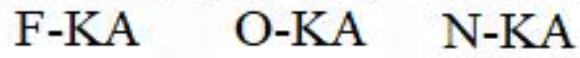

$\mathrm{B}-\mathrm{KA}$

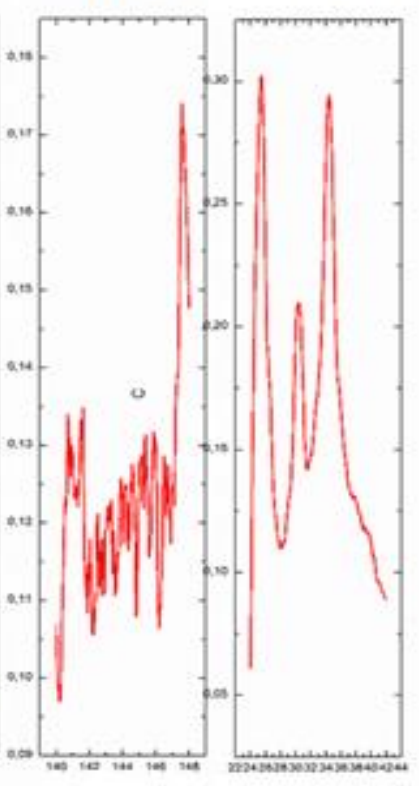

Figure 3 The intensities of detected elements versus diffraction angle obtained from PP sample

\section{References}

Akbaba U, Şahin Y, Türkez H. 2012. The element contents in chickpeas grown under organic and conventional farming regimes using WDXRF analysis for human nutrition and health. Turk J. Phys., 36(2): 279-287.

Akdeniz V, Kınık Ö, Yerlikaya O, Akan E. 2016. İnsan sağlığı ve beslenme fizyolojisi açısından çinkonun önemi. Akademik Gida, 14(3): 307-314.

Arun M, Asha, VV. 2007. Preliminary studies on antihepatotoxic effect of Physalis peruviana Linn.(Solanaceae) against carbon tetrachloride induced acute liver injury in rats. J. Ethnopharmacol., 111(1): 110-114. DOI: 10.1016/j.jep.2006.10.038

Babalar M, Sokri SM, Lesani H, Asgari MA, Barker AV. 2015. Effects of nitrate: ammonium ratios on vegetative growth and mineral element composition in leaves of apple. J. Plant Nutr., 38(14), 2247-2258. DOI: 10.1080/01904167 .2014 .964365

Akbaba U, Sahin Y, Turkez, H. 2012. Comparison of element contents in haricot beans grown under organic and conventional farming regimes for human nutrition and health. Acta Sc1. Pol-Hortoru. 11(2), 117-125.

Chien W, Sun QY, Lee KL, Ding LW, Wuensche P, TorresFernandez LA, Tan SZ, Tokatly I, Zaiden N, Poellinger L, Mori S, Yang HJ, Tyner W, Koeffler HP. (2015) Activation of protein phosphatase $2 \mathrm{~A}$ tumor suppressor as potential treatment of pancreatic cancer. Mol. Oncol., 9: 889-905. DOI: 10.1016/j.molonc.2015.01.002

Demirtaş A, 2010. Bor'un İnsan Beslenmesi ve Sağlı̆̆ Açısından Önemi. Atatürk Üniversitesi Ziraat Fakültesi Dergisi, 41(1): 75-80.

Dkhil MA, Al-Quraishy S, Diab MM, Othman MS, Aref AM, Moneim, AEA. 2014. The potential protective role of Physalis peruviana L. fruit in cadmium-induced hepatotoxicity and nephrotoxicity. Food Chem. Toxicol., 74: 98-106. DOI: 10.1016/j.fct.2014.09.013 
Etzbach L, Pfeiffer A, Weber,F, Schieber, A. 2018. Characterization of carotenoid profiles in goldenberry (Physalis peruviana L.) fruits at various ripening stages and in different plant tissues by HPLC-DAD-APCI-MSn. Food Chem. 245: 508-517. DOI: 10.1016/j.foodchem.2017.10.120

Fang ST, Liu JK, Li, B. 2012. Ten new withanolides from Physalis peruviana. Steroids, 77(1-2): 36-44. DOI: 10.1016/j.steroids.2011.09.011.

Galvis, JA, Fischer, G, Gordillo, OP. 2005. Cosecha y poscosecha de la uchuva. Avances en cultivo, poscosecha y exportación de la uchuva (Physalis peruviana L.) en Columbia, Bogotá, Unibiblos.

Golubkina N, Seredin MT, Antoshkina MS, Kosheleva OV, Teliban CG, Caruso G. 2018. Yield, Quality, Antioxidants and Elemental Composition of New Leek Cultivars under Greenhouse Organic or Conventional System. Horticulturae, 4 (4): 39. DOI:10.3390/ horticulturae4040039

Hassan HA, Serag HM, Qadir MS, Ramadan, MF. 2017. Cape gooseberry (Physalis peruviana) juice as a modulator agent for hepatocellular carcinoma-linked apoptosis and cell cycle arrest. Biomed. Pharmacother., 94: 1129-1137. DOI: 10.1016/j.biopha.2017.08.014.

Hegedűs A, Balogh E, Engel R, Sipos, BZ, Papp J, Blázovics A, Stefanovits-Bányai É. 2008. Comparative nutrient element and antioxidant characterization of berry fruit species and cultivars grown in Hungary. HortScience., 43(6): 1711-1715.

Lan YH, Chang FR, Pan MJ, Wu CC, Wu SJ, Chen SL, Wang SS, Wu MJ, Wu, YC. 2009. New cytotoxic withanolides from Physalis peruviana. Food Chem., 116(2): 462-469. DOI:10.1016/j.foodchem.2009.02.061
Martínez-Ballesta MC, Dominguez-Perles R, Moreno DA, Muries B, Alcaraz-López C, Bastías E, Viguera CG, Carvajal, M. 2010. Minerals in plant food: effect of agricultural practices and role in human health. A review. Agron. Sustain. Dev., 30(2): 295-309.

Pravina P, Sayaji D, Avinash M. 2013. Calcium and its role in human body. Int. J. Res. Pharm. Biomed. Sci, 4(2): 659-668.

Ramadan MF. 2011. Bioactive phytochemicals, nutritional value, and functional properties of cape gooseberry (Physalis peruviana) An overview. Food Res. Int., 44(7): 1830-1836. DOI:10.1016/j.foodres.2010.12.042.

Sang-ngern, M, Youn UJ, Park EJ, Kondratyuk TP, Simmons CJ, Wall MM, Ruf M, Lorch SE, Leong E, Pezzuto JM, Chang, L. C. (2016). Withanolides derived from Physalis peruviana (Poha) with potential anti-inflammatory activity. Bioorganic Med. Chem. Lett., 26(12): 2755-2759. DOI: 10.1016/j.bmcl.2016.04.077

Stewart TA, Azimi I, Thompson EW, Roberts-Thomson SJ, Monteith GR. 2015. A role for calcium in the regulation of ATP-binding cassette, sub-family $\mathrm{C}$, member 3 (ABCC3) gene expression in a model of epidermal growth factormediated breast cancer epithelial-mesenchymal transition. Biochem. Biophys. Res. Commun. 458(3): 509514. DOI: 10.1016/j.bbrc.2015.01.141

Wojcieszek J, Ruzik L. 2016. Operationally defined species characterization and bioaccessibility evaluation of cobalt, copper and selenium in Cape gooseberry (Physalis Peruviana L.) by SEC-ICP MS. J. Trace Elem. Med. Biol., 34: 15-21. DOI: 10.1016/j.jtemb.2015.12.001.

Wu SJ, Ng LT, Lin DL, Huang SN, Wang SS, Lin CC. 2004. Physalis peruviana extract induces apoptosis in human Hep G2 cells through CD95/CD95L system and the mitochondrial signaling transduction pathway. Cancer Lett., 215(2): 199208. DOI: $10.1016 /$ j.canlet.2004.05.001 